\title{
THE EVIDENTIAL VALUE OF BLOOD TESTS
}

A court of last-resort recently, for the first time in American legal history, passed upon the admissibility in evidence of the results of a blood test designed to show that the defendant was not the father of a certain child, as had been charged. The lower court's refusal to admit such evidence was sustained, on the ground that the defendant had failed to prove that the blood test is sufficiently accurate to have the requisite probative value for legal evidence. ${ }^{\mathrm{I}} \mathrm{It}$ is believed that an examination of the subject in the light of the results of medical research during the past decade ${ }^{2}$ will indicate that the court might well have taken a more liberal attitude, ${ }^{3}$ and that the reliability of blood tests has been proved to the extent that they may now be considered valuable aids in the administration of justice.

Since the opening of the twentieth century, medical research has established a number of important propositions as to the nature and characteristics of human blood. All human blood may be classified into certain definite groups. The blood of a particular individual may be attributed to one of these groups on the basis of its agglutination or coagulation with other types of blood serum. These blood characteristics are transmitted from generation to generation according to the Mendelian laws of heredity. Finally, on the basis of these blood groupings, the possibility or impossibility that an individual having blood of a certain type was born from the union of two other individuals of ascertained types may be determined. 4

Certain conclusions may be drawn from these propositions as to the use of the blood test in cases of disputed paternity: (I) If a child's blood falls within a - group to which might be attributed the blood of a union of the alleged parent and the undisputed parent, it is possible, though not certain, that the child is their offspring; (2) on the other hand, if the child's blood is not such a possible

I State v. Damm, ${ }_{252}$ N.W. 7 (S.D. I933). The court said: "We base such holding specifcally upon the proposition that it does not sufficiently appear from the record in this case that modern medical science"is agreed upon the transmissibility of blood characteristics to such an extent that it can be accepted as an unquestioned scientific fact that, if the blood groupings of the parents are known, the blood group of the offspring can be necessarily determined, or that, if the blood groupings of the mother and child are known, it can be accepted as a positively established scientific fact that the blood group of the father could not have been a certain specific characteristic group." (252 N.W. 7, I2).

${ }^{2}$ See Lee, Blood Tests for Paternity, I2 Am. Bar Assn. Jour. 44I (r926). Mr. Lee offers a learned discussion of medical theory based upon Ottenberg's work in I921-22.

3 For some recent liberal developments in the field of evidence, see Funk v. United States, 290 U.S. 37I, 54 Sup. Ct. 212 (r933), in which the wife of a defendant was permitted to testify on his behalf in a criminal trial; and United States v. Provident Trust Co., 290 U.S. 6r4, 54 Sup. Ct. $3^{89}$ (1934), in which evidence of incapacity to have issue was admitted.

4 Ottenberg, Heredity Blood Qualities; Medico-Legal Applications of Human Blood Grouping, 6 Jour. Immunology $3_{3}$ (I92I). His conclusion as to the legal value of such tests is emphatic: "The number of instances in which the group blood test is of value is limited, but within those limits its evidence is exclusive." 
resultant, then it is certain that the person allegedly a parent is not such in fact. 5

These conclusions were accepted at an early date by continental courts, and numerous cases may be found in which blood tests were utilized to determine parentage. ${ }^{6}$ In England and America, however, no reported case has been found which discloses the use of such a test; ${ }^{7}$ in Ireland, two lower courts have, quite recently, admitted such evidence. ${ }^{8}$ Until about ten years ago, the reluctance of the courts to admit evidence of this type was justified in part by the lack of agreement among medical experts as to the theories involved, although there was complete uniformity as to the practical results. ${ }^{9}$ These theoretical difficulties were ended by Bernstein's discoveries in I924. In addition, a further set of tests was developed in 1928 which clarifies and renders more exact the classification originally developed by Bernstein, and makes it possible in some instances to determine differences within the categories formerly recognized..$^{x 0}$

$s$ The possibilities are expressed in tabular form as follows [from Bernstein, $23 \mathrm{Klin}$. Wchnschr. 1495 (I924); 37 Ztschr. f. Indukt. Abstram. u. Vererbungs. 237 (I925)]:

Heredity of the Landsteiner Blood Groups (Bernstein)

Groups of Parents

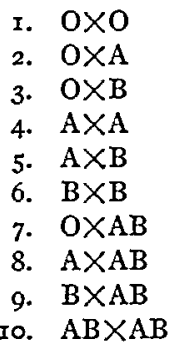

$$
\text { Groups of Children }
$$
Possible

O

$\mathrm{O}, \mathrm{A}$

$\mathrm{O}, \mathrm{B}$

$\mathrm{O}, \mathrm{A}$

$\mathrm{O}, \mathrm{A}, \mathrm{B}, \mathrm{AB}$

$\mathrm{O}, \mathrm{B}$

$\mathrm{A}, \mathrm{B}$

$A, B, A B$

$\mathrm{A}, \mathrm{B}, \mathrm{AB}$

$A, B, A B$

\section{Groups of Children} Impossible

$\mathrm{A}, \mathrm{B}, \mathrm{AB}$

$\mathrm{B}, \mathrm{AB}$

$A, A B$

$B, A B$

none

$\mathrm{A}, \mathrm{AB}$

$\mathrm{O}, \mathrm{AB}$

$\mathrm{O}$

0

O

'See Weiner's articles, 2x Jour. Immunology I 57 (I93I); 24 Jour. Immunology 443 (I933); and 186 Am. Jour. Med. Sci. 257 (I933); also, editorial, 85 Jour. Am. Med. Assoc. 6I 2 (I93).

7 In Weiner, Determination of Non-Paternity, I86 Am. Jour. Med. Sci. 257, 264-265 (1933), a number of instances of the use of the blood tests in trial courts is set out. See also Beuschel v. Manowitz, I U.S.L.W. 408 (N.Y. Sup. Ct. I934), in which it was held that the defendant was entitled to an order requiring plaintiff and her child to submit to blood tests.

${ }^{8}$ See 66 Ir. L. T. 64 , I I I (I932). Both were lower court cases. In the first, the defendant was convicted, but secured a new trial when, on appeal, a blood test was held admissible to show the impossibility of the alleged paternity. In the second, the test appeared unsuccessful.

9 For example, see the controversy between Ottenberg and Buchanan: Ottenberg, 77 Jour. Am. Med. Assoc. 682 (x921); 78 ibid. 873 (I922); 79 ibid. 2137 (1922). Buchanan, 78 ibid. 89 (1922); 79 ibid. I80 (1922). Ottenberg's position was apparently the strongest, in view of the preponderance of current medical authority supporting his theory. See Weiner, 99 Jour. Am. Med. Assoc. 242 (1932), who says that the only disagreement was over the theory proposed to explain the undisputed law.

ro Bernstein's work was fairly conclusive, and research since that time has failed to reveal a single exception to the theory he stated, although such eminent scientists as Schiff, Thomsen, Snyder, Furuhata, and Vuori have worked on the problem. Weiner has shown that the theory does not change the law itself, as previously formulated; but that it offers additional opportu- 
Even with this added test, the number of blood groups is small, and the number of people whose blood falls within any one group is large. No claim is made that blood tests will determine that an individual is the parent of a particular child; their present value lies in determining, in a well-defined class of instances, that a particular individual could not be the parent of a particular child. It has been estimated that the chances of establishing non-paternity by means of the earlier (Bernstein) tests alone are about one in six; if in addition the new tests

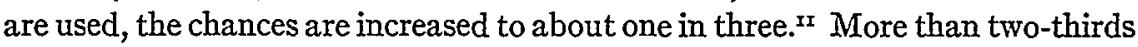
of all cases in New York City in which new-born infants have been accidentally interchanged in hospitals have thus been solved.12

As legal evidence, the blood test definitely seems to belong in the category of "expert opinion," since the conclusions are based upon medical research, involving propositions totally unfamiliar to the layman. ${ }^{13}$ Where the result of the test is to show that the person charged with being the child's parent might be such, the probative value of the evidence is admittedly low, and its prejudicial effect in a jury trial, particularly in a criminal case, may be high. Thus it may properly be excluded where its introduction is sought to prove paternity. ${ }^{{ }_{4}}$ Where, however, the result shows that the person charged could not be the parent of a child, its value as proof of non-paternity is unquestioned in medical circles; and, it is believed, the same recognition should be accorded to it in courts of law. ${ }^{\mathrm{x}}$

\section{Wirliam Lours Fiacks}

nities for the proof of non-paternity. Weiner, Determination of Non-Paternity, I86 Am. Jour. Med. Sci. 257 (1933).

The new tests, developed by Landsteiner and Levine, deal with certain additional substances in the blood. See Landsteiner and Levine, 47 Jour. Exp. Med. 757 (I928); 48 ibid. 73 I (r928). Experiments in confirmation of the theory, conducted by Schiff, Weiner, Vaisberg, Thomsen, Clausen, and others, number about 20,000, and no exception has been found. For example, see Weiner and Vaisberg, 20 Jour. Immunology $37 \mathrm{I}$ (193r); Weiner, Rothberg, and Fox, 23 Jour. Immunology 63 (I932).

Ir Weiner, Lederer, and Polayes, r9 Jour. Immunology 259 (1930); Hooker and Boyd, 6 ibid. 45 I (I929).

12 Weiner, supra note 7,259 .

${ }_{13}$ But see Lee, supra note 2 , who argues that blood tests are to be classed as real evidence. On the use of other Mendelian traits in evidence, see I Wigmore, Evidence (2d èd. I923), § I65.

${ }^{14}$ See 4 Wigmore, Evidence (2d ed. r923), § r904.

${ }^{15}$ In criminal cases the accused, if he fears that the results of the blood test will be unfavorable and that the court may not exclude the testimony on grounds of prejudice, may properly refuse to submit to the test since he may thus incriminate himself. Cf. Hinton, Cases on Evidence (2d ed. I930), 186-221. 